\title{
The Role of Trust on Perceived Usefulness and Perceived Ease of Use towa rd Purchase Intention among Yogyakarta's Students
}

\author{
Refi Primanda \\ Universitas Islam Indonesia \\ Alldila N.A. Setyaning \\ Universitas Islam Indonesia \\ Anas Hidayat ${ }^{*}$ \\ Universitas Islam Indonesia \\ Sri Rejeki Ekasasi \\ Sekolah Tinggi Ilmu Manajemen - YKPN Yogyakarta \\ Email: anas.hidayat@uii.ac.id
}

\begin{abstract}
This research aims to understand the impact of online consumer reviews on consumers' trust and purchase intention. The variables involved in this paper are perceived usefulness, perceived ease of use, trust, and purchase intention. A total of 210 responses from distributed questionnaire were obtained from students who already had online shopping experience before and lived in Yogyakarta, Indonesia. To collect the data, this study used purposive sampling method. The data was analyzed by using Structural Equation Modeling (SEM) analysis method with the help of PLS software. The findings from this research were consumers' trust and their intention to shop online were positively and significantly affected by perceived usefulness and perceived ease of use of OCRs. Clearly, those attributes of OCRs were linked to the development of the shopping environment, which consequently could affect sales.
\end{abstract}

Keywords: perceived usefulness, perceived ease of use, trust, purchase intention

\section{Introduction}

People believe that almost all of our activities nowadays cannot be separated from the Internet and technology. This trend applies to consumer shopping behavior as well. With ecommerce, consumers can simply conduct multiple transactions without having to leave their comfortable couch at home. Online marketplace has become an extremely popular platform for shopping, shifting consumers behavior from brick-and-mortar transactions to online transactions. Online platforms such as official websites, social media, blogs, online discussion forums, and online marketplace also help distribute information vastly and continuously $24 / 7$.

Indonesia has an enormous potential for digital market development. According to a survey by Association of Internet Service Provider Indonesia (APJII) (2017), Indonesia internet users in 2016 were around 132.7 million users (more than half of the national total population), and it is still growing. The same survey shows that $97.4 \%$ of Indonesia internet users use the Internet for social media and $91.3 \%$ of Internet users in Indonesia use the Internet for commercial use. The understanding of Internet for commerce spread widely in Indonesia and become a good base for small-to-medium enterprise to expand their businesses 
online. This premise is proven by the data presented by APJII that 130 million people search the goods and services by online. Then, 84.2 million users have online transactions by 2016 .

In the e-commerce industry, there are several things that generate pros and cons that might determine the consumers buying decision, such as: price, reviews, and seller's trustworthiness. Consumers are seeking to get the best value for money based on the price they are paying. Positive reviews may affect sales and buyers' attitude (Helversen et al., 2018). Consumers also tend to seek for trustworthy sellers from various indicators, for instance ratings given by previous consumer, the amount of goods sold, seller's company background, etc.

Online shopping gives a different shopping experience for customers and sellers compared to shopping in a physical store. As a result, buyers often feel worried when it comes to the reality of product quality by watching the display pictures, payment security, or the delivery assurance (Lee \& Ma, 2012). Uncertainty information has impact to the products, processes, and psychological because sellers do not deliver well the value to the customers. Meanwhile, sellers possibly have risk because buyer sometime cancel the order without confirmation. Hence, trust becomes one of the most important issues to be solved to enhance both buyers and the sellers' e-commerce experience.

With the rise of virtual communities, trustworthiness could be managed with the presence of Online Consumer Review (OCR). OCR is a review which is conducted by experienced buyer. The ability to provide information on alternatives also assists consumers to make better decisions and achieve higher satisfaction. By OCR, information can be obtained before making a purchase. As technology advances, information becomes more transparent, and product information becomes more accessible for consumers. Amongst all available information, OCRs are more trustworthy source of information based on consumers because it is more personal and genuine comparison to information by sellers or advertisements (Lee \& Ma, 2012; Thakur, 2018). Consumers usually rely on OCR to be sure of their purchase by confirming that peers approve the product (Hennig-Thurau et al., 2004). In conclusion, OCRs influence potential buyers' decision-making process and is regarded as a reliable source of product information.

Thus, the research objective is to examine the effectiveness of these OCRs judgement from the perceived usefulness and ease of use that shape consumers' trust on e-commerce that create purchase intention through online marketplace. To find out the effectiveness of the use of OCRs, a comprehensive study needs to be carried out both in terms of e-commerce businesses and e-commerce users. The lack of e-commerce usage in Indonesia is a challenge for the company.

\section{Literature Review}

\section{Perceived Usefulness and Perceived Ease of Use}

Davis (1989) suggested that perceived usefulness and perceived ease of use are the main determinant of system use and information adoption. Perceived usefulness is defined as the degree to which an individual believes that using a particular system enhances his or her productivity (Davis, 1989). In other words, individuals are likely to adapt to a new technology if they regard it useful for achieving certain goals and helpful for them to perform the job better. Moreover, perceived ease of use is defined as the degree an individual believes that 
using a particular system is effortless (Davis, 1989). With the various choices available, prospective consumers are more likely to choose an option that is easier to use and requires the least physical or mental effort (Yang, 2013).

Based on the study by Hennig-Thurau et al. (2004) found that OCRs reduce information search time and help consumers sort the best option from a wide range of products. OCRs can also provide convenience for both parties. In the online shopping environment uncertainty becomes one of the labels users perceived. Thus, trust plays an important role. Ho \& Chen (2014) found that the success of online shopping channel mirrors consumers' perceived low level of risk and high level of trust which directly increase consumers' intention to shop online. From consumers' perspective, opinions originally posted by fellow consumers are seen to be more reliable and genuine compared to advertisements by sellers (Dellarocas, 2003; Sher \& Lee, 2009). Mortazavi et al. (2014) release the same statement whereby peer's recommendation is more trustworthy compared to online advertisements. The quality of OCRs, in this case "helpfulness" is also found to influence product sales (Park et al., 2007). Bach (1967) mentioned that consumer reviews can be considered good if they have: (1) trustworthy perception, (2) problem-solving, and (3) insight mediation. Additionally, positively reviewed products are sold better than the one that are not (Helversen et al., 2018). Perceived ease of use is also found influencing trust (Aghdaie et al., 2011). Useful, clear and understandable/relatable of available information tends to reduce anxiety because of asymmetric information and the increasing seller trust (Ho \& Chen, 2014).

According to Akerlof (1970), asymmetric information is a condition where one party has more or better information than the other parties. With the perception that a seller is exploiting on the buyer-seller relationship, perceived ease of use increase consumer trust (Gefen et al., 2003). McKnight \& Chervany (2002) mentioned that trust in online shopping is not only between buyers and sellers, but trust is also happened between buyers and the supporting systems. Sufficient information sources also improve consumers' trust. Consumer trust sellers who provide OCR feature more than other online sources (Elwalda et al., 2016). Given the trustworthiness and credibility of OCR (Hu, Liu, Bose, \& Shen, 2010), this feature in e-commerce is likely to be a key factor in influencing the consumer's purchase decision making process (Elwalda et al., 2016). OCRs more help buyers in figuring out the indication of product value than to compare other products. The ability to provide information on alternatives helps consumers to make better decisions and better experience with higher satisfaction rate (Kotler et al., 2004). In conclusion, online review systems are generally employed to improve consumers' trust in doing online shopping (Razak et al., 2014; Elwalda, et al., 2016).

\section{H1: Perceived usefulness of OCRs influence consumers' trust in e-commerce.}

H2: Perceived ease of use of OCRs influence consumers' trust in e-commerce.

\section{Trust}

In "A social commerce investigation of the role of trust in a social networking site on purchase intentions", Hajli e al. (2016) mentioned that trust is a belief in the reliability, truth, and ability of the exchange party. In the context of online shopping, trust is a positive expectation that enhances the consumers' beliefs that other people do not act opportunistically (Ho \& Chen, 2014). For instance, buyer expects the product to be received be the same as the product advertised by the seller. 
As an intermediary feature, the system of marketplace itself needs to have a clear terms and conditions that protects both buyers and sellers equally, creating a sense of security. Terms and conditions enable consumers to reduce the social complexity (Razak et al., 2014). Therefore, complex and long-term transaction is possible. The higher the degree of trust a consumer has in particular website, the higher the probability of consumer to have the intention of shopping on that website (Razak et al., 2014). This shows the strong relationships between trust and purchase intention (McKnight \& Chervany, 2002).

H3: Trust in e-commerce sites that provide OCR feature influence consumers' intention to shop online.

\section{Purchase Intention}

Purchase intention is defined as the likelihood of the future purchase of a product or service (Kim \& Park, 2013). According to Gefen et al. (2003), intention is a determinant of behavior and is defined as "the power of one's intention to carry out certain behaviors". Then, purchase intentions in online shopping contexts refer to the consumers' intentions to engage in online purchases from sellers in e-commerce site (Hajli et al., 2016), and it depends on consumers' trust on the seller (Gefen et al., 2003).

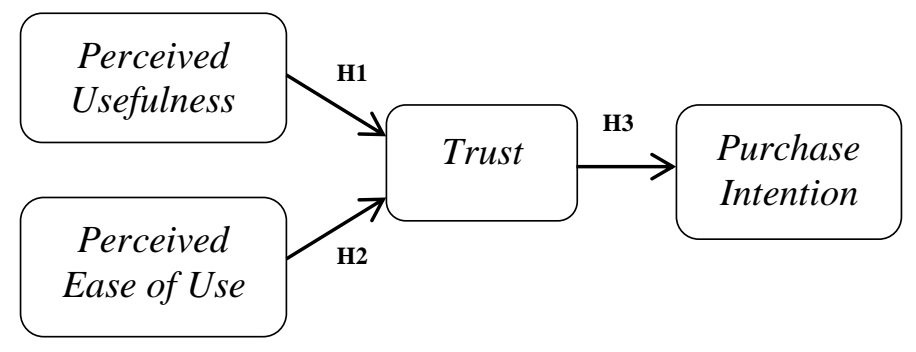

Figure 1. Research Framework

\section{Research Method}

The analytic approach used in this research was quantitative method, utilizing questionnaire as data source, and Likert scale as itemized rating scale to assess data from respondents. Quantitative method attempts to measure and grade certain phenomena and their intensity based on the use of statistical techniques to understand certain aspects of interest on the population or sample under study (Suarez et al., 2017).

A total of 210 responses from distributed questionnaire were obtained from students who live in Yogyakarta and already had online shopping experience before. This research utilized factor analysis and Structural Equation Modeling (SEM). Purposive sampling was chosen as a sampling method in this research due to the researcher's specific requirements in respondents' characteristics. The respondents in this research were required to have prior online shopping experience.

\section{Validity and Reliability Test}

According to Neuman (2014), construct validity is tested by Confirmatory Factor Analysis(CFA) where the results are used to see the level of intercorrelation within variables. If the value is above 0.5, it means that the item is valid (Hair Black, Babin, and Anderson, 
2010). Discriminant validity is accepted if the square root of the Average Variance Extracted (AVE) is greater than the correlation between constructs and loading indicators value is low (Sholihin and Ratmono, 2013). Reliability test is obtained to ascertain the extent to which the measuring instrument used provides valid and consistent results. Hair et al. (2010) stated that the internal consistency of the question items in the questionnaire is measured using Cronbach's alpha coefficient values greater than 0.6.

Table 1. Average Variances Extracted Value

\begin{tabular}{ll}
\hline Variable & AVE \\
\hline Perceived Usefulness & 0.500 \\
Perceived Ease of Use & 0.574 \\
Trust & 0.587 \\
Purchase Intention & 0.503 \\
\hline
\end{tabular}

Source: Primary Data (2019)

Based on the Table 1 shows that all variables met the minimum criteria AVE value of 0.5. Next, the question items need to be tested to find out how valid they are. For the factor loading value of each item, it is recommended to be above 0.5 (Hair et al., 2010). As shown on the Table 2, the value of all loading factors is above 0.5 .

Table 2. Cross Loading and Factor Loading per Items

\begin{tabular}{lcccc}
\hline & PU & PEOU & TRUST & PI \\
\hline PU1 & 0.666 & & & \\
PU2 & 0.756 & & & \\
PU3 & 0.678 & & & \\
PU4 & 0.694 & & & \\
PU5 & 0.711 & & & \\
PU6 & 0.682 & & & \\
PEOU1 & & 0.749 & & \\
PEOU2 & & 0.737 & & \\
PEOU3 & & 0.765 & & \\
PEOU4 & & 0.778 & & \\
TRUST1 & & & 0.714 & \\
TRUST2 & & & 0.812 & \\
TRUST3 & & & 0.796 & \\
TRUST4 & & & 0.738 & \\
PI1 & & & & 0.637 \\
PI2 & & & & 0.788 \\
PI3 & & & & 0.696 \\
PI4 & & & \\
PI5 & & & & \\
\hline
\end{tabular}

Source: Primary Data (2019) 
INOBIS: Jurnal Inovasi Bisnis dan Manajemen Indonesia

Volume 03, Nomor 03, Juni 2020

Refi Primananda, Alldila N.A.Setyaning, Anas Hidayat, Sri Rejeki Ekasari

Table 3. Comparison of AVE Square Roots with Correlations

\begin{tabular}{lllll}
\hline & PU & PEOU & TRUST & PI \\
\hline PU & 0.698 & 0.294 & 0.240 & 0.220 \\
PEOU & 0.294 & 0.757 & 0.244 & 0.305 \\
TRUST & 0.240 & 0.244 & 0.766 & 0.098 \\
PI & 0.220 & 0.305 & 0.098 & 0.709
\end{tabular}

Source: Primary Data (2019)

Table 3. shows that the AVE square root value of each construct is different or greater when compared to the correlation value between each construct. Therefore, it can be concluded that the measurement by discriminant test for each construct item is valid. The next stage is to conduct a construct reliability test. This is done to measure the consistency of the question items in measuring a construct. Based on the Table 1.4, the coefficient value of each variable is above 0.7 , this indicates that all constructs have good reliability.

Table 4. Reliability Testing Result

\begin{tabular}{lcl}
\hline \multicolumn{1}{c}{ Variable } & $\begin{array}{c}\text { Composite Reliability } \\
\text { Coefficients }\end{array}$ & Details \\
\hline Perceived Usefulness & 0.851 & Reliable \\
Perceived Ease of Use & 0.843 & Reliable \\
Trust & 0.850 & Reliable \\
Purchase Intention & 0.834 & Reliable \\
\hline
\end{tabular}

Source: Primary Data (2019)

\section{Data Analysis and Discussions}

Table 5. The Model Suitability Test Result

\begin{tabular}{ll}
\hline \multicolumn{1}{c}{ Indicators } & Value \\
\hline Average path coefficient (APC) & $\mathrm{P}<0.001$ \\
Average $R$-squared (ARS) & $\mathrm{P}<0.001$ \\
Average adjusted $R$-squared (AARS) & $\mathrm{P}<0.001$ \\
Average block VIF (AVIF) & 1.039 \\
Average full collinearity VIF (AFVIF) & 1.148 \\
Tenenhaus GoF (GoF) & 0.209
\end{tabular}

Source: Primary Data (2019)

The following result of the indicator values can be seen on the Table 1.5. Overall, all the indicators of the model fit shows that the model is fit. 


\section{Hypothesis Testing}

The path coefficient $(\beta)$ and the significance level ( $p$-value) need to be considered. The level of significance used in this study was $5 \%(\mathrm{p}<0.05)$. Path analysis for hypothesis testing in this study shows in the Figure 1.2 that explains the direct effect and interaction of moderation,

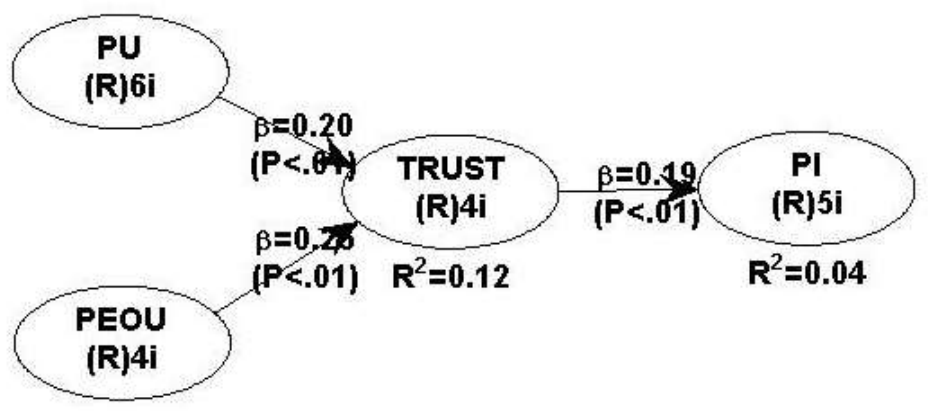

Figure 2. Model Path Analysis for Hypothesis Testing

Table 6. Path Analysis for Hypothesis Testing

\begin{tabular}{|c|c|c|c|c|}
\hline \multirow{3}{*}{ Variable } & \multicolumn{4}{|c|}{$\beta \& p$-value } \\
\hline & \multicolumn{4}{|c|}{ direct effect } \\
\hline & PU & PEOU & TRUST & PI \\
\hline $\begin{array}{l}\text { Perceived } \\
\text { Usefulness } \\
\text { (PU) }\end{array}$ & & & & \\
\hline $\begin{array}{l}\text { Perceived } \\
\text { Ease of Use } \\
(\mathrm{PEOU})\end{array}$ & & & & \\
\hline $\begin{array}{l}\text { Trust } \\
\text { (TRUST) }\end{array}$ & $0.202 * *$ & $0.252^{* *}$ & & \\
\hline $\begin{array}{l}\text { Purchase } \\
\text { Intention (PI) }\end{array}$ & & & $0.194 * *$ & \\
\hline
\end{tabular}

Source: Primary Data (2019)

H1 - The first hypothesis proposed that perceived usefulness variable has a positive and significant influence toward trust variable. The result of perceived usefulness of OCRs on trust was significant because the probability value was $0.001(\mathrm{p}<0.05)$ and the path estimate was 0.202 (H1 supported). In sum, perceived usefulness of OCRs influence consumers' trust in e-commerce had positive result and the hypothesis was accepted. The 
data shows that the higher the value of perceived usefulness variable, the higher the consumers trust in particular e-commerce site.

H2 - The second hypothesis proposed that perceived ease of use of OCRs has a positive and significant influence toward trust. The test on perceived ease of use of OCRs toward trust was proven significant because the value probability was $0.001(\mathrm{p}<0.05)$ and the path estimate was 0.252 ( $\mathrm{H} 2$ supported). In sum, perceived ease of use of OCRs influence consumers' trust in e-commerce had positive result and the hypothesis was accepted. The data showed that the higher the value of perceived ease of use variable, the higher the consumers' trust in particular e-commerce site.

H3 - The third hypothesis proposed that trust on e-commerce sites that provide OCRs has a positive and significant influence toward purchase intention. The test on trust on ecommerce sites that provide OCRs toward purchase intention was proven significant because the value probability was $0.002(\mathrm{p}<0.05)$ and the path estimation was 0.194 (H3 supported). In sum, trust on e-commerce sites that provide OCRs influence consumers' intention to shop online have positive result and the hypothesis was accepted. The data showed that the higher the value of trust variable, the higher the consumer's intention to purchase through an online shopping site.

\section{Discussion}

The result reveals that perceived usefulness of OCRs significantly influenced consumers' trust and online purchase intentions. This shows that OCRs are considered important to be read before consumers made actual purchase. In addition, perceived usefulness of OCRs as the determination to improve consumers' online shopping effectiveness and their online shopping efficiency, boosted the level of trust in the platform used, including the seller of goods to be purchased from, because consumers chose selectively the kind of product to be purchased, the source of the product purchased, and the platform used to purchase the product. The result of this research is consistent with Elwalda, et al. (2016) and Gefen, et al. (2003), which stated that perceived usefulness has a significant impact toward consumers' trust and purchase intention.

Second, the result reveals that the perception of the ease of use of OCRs significantly influenced trust in consumers' purchase intentions. This shows that the influence of perceived ease of use variable affects trust to have purchase intention. Useful, clear, and easily understood information created by OCRs arelikely to decrease confusion caused by asymmetric information (Ho \& Chen, 2014). On the other hand, consumers' purchase intention can be increased with a combination of low level of risk and high level of trust. The result of this research is in line with some previous researches (Bart, et al., 2005; Ho \& Chen, 2014), where perceived ease of use influences trust and purchase intention.

Finally, the results indicate that trust significantly influenced consumers' purchase intentions. The finding of this research confirms that trust is a key antecedent of consumers purchase intention in shopping online. The result is in line with some earlier researches (Gefen et al., 2003; Ho \& Chen, 2014; Elwalda et al., 2016) which states that consumers who perceive trust from e-commerce sites that provide OCR feature are likely to perform online purchase through those sites. 


\section{Conclusions and Recommendations}

\section{Conclusions}

Based on the results of data analysis, the all hypotheses proposed in this research are all accepted. Meaning that the variable of purchase intention is significantly influenced by perceived usefulness and perceived ease of use (TAM) and also trust. With regard to general implication, this research shows that OCRs play an important role in affecting consumers' trust and purchase intention. Therefore, researcher suggests e-commerce site developers/ sellers to allow consumers to post reviews related to the product offered. Communication between consumers in this case through OCRs in online shopping sites appear to provide useful information that can be beneficial for both buyers (i.e. improve confidence, improve trust, and obtain clear information) and sellers (i.e. gain consumers' trust, improve reputations, and increase sales).

\section{Research Limitations}

First, this research only focuses on how perceived usefulness and perceived ease of use affecting trust and purchase intention. There can be so much more variables that can affect purchase intention. Second, this research is conducted in Yogyakarta, Indonesia. Consumer behavior, shopping lifestyle, and culture might vary among other places. Third, due to the limited cost and time for this research, respondent of this research not fully represent all consumers of e-commerce.

\section{Recommendations}

For further empirical studies, researcher suggests to fully specify the development of purchase intention. Additional exploratory work is required to utilize other relevant observed variables and constructs that may have a potential relationship on purchase intention.

Consumers are satisfied when they receive a good quality of shopping experience, in this case online shopping. Looking at the benefit given by OCRs, companies must give more attention in utilizing this feature in their system, and it is not only for their products, but company also brings in their services such as customer care, online chat, etc. Furthermore, retailers and marketers can also help by understanding the power and benefits of OCRs which can relate to their products and services to improve their business performance. Thus, purchase intention on e-commerce increase.

Finally, because every individual has their own capability to process information, company must make sure the user interface system is understandable and easy to use. Thus, the content become easier to understand. Upon this, researcher suggests managers to evaluate other ways of designing and implementing advertising campaigns that have a clearer purpose. If the advertising campaign is for building awareness, advertising trough radio, newspaper, and other similar marketing communication tool can be used. When the advertising campaign is to enforce purchase intention, sales promotion and direct marketing can also be applied. Besides, targeting population with an appropriate marketing strategy must be beneficial to companies engaged in e-commerce. 


\section{References}

Aghdaie, S. F., Piraman, A., \& Fathi, S. (2011). An Analysis of factors affecting the consumer's attitude of trust and their impact on internet purchasing behavior . International Journal of Business and Social Science, 147-158.

Alboqami, H., Al-Karaghouli, W., Baeshen, Y., Erkan, I., Evans, C., \& Ghoneim, A. (2015). Electronic word of mouth in social media: the common characteristics of retweeted and favourited marketer-generated content posted on Twitter (Vol. 9). London, UK: Inderscience Enterprises Ltd.

Bae, S., \& Lee, T. (2011). Product type and consumers' perception of online consumer reviews. Electronic Markets , 21 (4), 255-266.

Bart, Y., Shankar, V., Sultan F. \& G.L., Urban. (2005). "Are the drivers and role of online trust the same for all web sites and consumers? A large-scale exploratory empirical study." Journal of Marketing: 133-152.

Cakir, E., \& Solak, E. (2015). Attitude of Turkish EFL Learners towards e-Learning through Tam model. Procedia - Social and Behavioral Sciences , 596-601.

Choi, J. K., \& Ji, Y. G. (2015). Investigating the importance of trust on adopting an autonomous vehicle . International Journal of Human-Computer Interaction , 692702.

Davis, F. D. (1989). Perceived usefulness, perceived ease of use, and user acceptance of information technology. MIS Quarterly, 13 (3), 319-340.

Dellarocas, C. (2003). The digitization of word-of-mouth: Promise and challenges of online feedback mechanisms. Management Science, 1407-1424.

Elwalda, A., Lu, K., \& Ali, M. (2016). Perceived derived attributes of online customer reviews. Computers in Human Behavior, 306-319.

Gefen, D., Karahanna, E., \& Straub, D. W. (2003). Inexperience and experience with online stores: the importance of TAM and trust. IEEE Transactions on Engineering Management , 50 (3), 307-321.

Ghozali, I. (2011). Aplikasi analisis multivariate dengan program IBM SPSS 19. Semarang: Badan Penerbit Universitas Diponegoro.

Hair, Joseph F., William C. Black, Barry J. Babin, \& Rolph E, Anderson. (2010), "Multivariate Data Analysis". ( $7^{\text {th }}$ ed.)., Englewood Cliffs, NJ: Prentice Hall.

Hajli, N., Sims, J., Zadeh, A. H., \& Richard, M.-O. (2016). A social commerce investigation of the role of trust in a social networking site on purchase intentions. Journal of Business Research, 133-141.

Hennig-Thurau, T., Gwinner, K. P., Walsh, G., \& Gremler, D. D. (2004). Electronic wordof-mouth via consumer-opinion platforms: What motivates consumers to articulate themselves on the internet . Journal of Interactive Marketing , 18 (1), 38-52.

Hennig-Thurau, T., Nalthouse, S. C., Friege, C., Gensler, S., Lobschat, L., Rangaswamy, A., et al. (2010). The impact of new media on customer relationships. Journal of Service Research , 13 (3), 311-330.

Ho, T. H., \& Chen, Y. (2014). Moderating effect of website types in the relationship between trust and consumers' intention to use online shopping. American Journal of Business and Management , 3 (1), 60-69. 
Hsu, C.-L., Lin, J. C.-C., \& Chiang, H.-S. (2013). The effects of blogger recommendations on customers' online shopping intentions. Internet Research, 69-88.

Hu, N., Liu, L., Bose, I., \& Shen, J. (2010). Does sampling influence customers in online retailing of digital music? Information Systems and E-Business Management , 8 (4), 357-377.

Kim, S., \& Park, H. (2013). Effects of various characteristics of social commerce (scommerce) on consumers' trust and trust performance. International Journal of Information Management, 318-332.

Lee, H., \& Ma, Y. J. (2012). Consumer perceptions of online consumer product and service reviews Focusing on information processing confidence and susceptibility to peer influence . Journal of Research in Interactive Marketing , 6 (12), 130-132.

McKnight, D. H., \& Chervany, N. L. (2002). What trust means in e-commerce customer relationships: an interdisciplinary. International Journal of Electronic Commerce , 35-59.

Mortazavi, M., Esfidani, M. R., \& Barzoki, A. S. (2014). Influencing VSN users' purchase intentions: The roles of flow, trust and eWOM. Journal of Research in Interactive Marketing , 8 (2), 102-123.

Razak, N. S., Marimuthu, M., Omar, A., \& Mamat, M. (2014). Trust and repurchase intention on online tourism services among malaysian consumers. Social and Behavioral Sciences , 577-582.

Sekaran, U. (2006). Metodologi Penelitian untuk Bisnis. Jakarta: Salemba Empat.

Sher, P. J., \& Lee, S.-h. (2009). Consumer skepticism and online reviews: an elaboration likelihood model perspective. Social Bahvior and Personality, 37 (1), 137-144.

Sholihin, Mahfud dan Ratmono, Dwi. (2013). "Analisis SEM-PLS dengan WrapPLS 3.0 Untuk Hubungan Nonlinear dalam Penelitian Sosial dan Bisnis". Yogyakarta: Penerbit ANDI.

Sidharta, S., \& Sidh, R. (2014). Pengukuran persepsi manfaat dan persepsi kemudahan terhadap sikap serta dampaknya atas penggunaan online shopping pada e-commerce. Journal Computech \& Bisnis , 8 (2), 92-100.

Sugiyono. (2016). Metode Penelitian Kuantitatif, Kualitatif, dan R\&D. Bandung: Alfabeta.

Sunyoto, D. (2014). Konsep Dasar Riset Pemasaran \& Perilaku Konsumen. Jakarta: CAPS (Center for Academic Publishing Service).

Thakur, R. (2018). Customer engagement and online reviews. Journal of Retailing and Online Services , 48-59.

Wang, J., Yang, Z., \& Brocato, E. D. (2018). An investigation into the antecedents of prepurchase online search. Information \& Managament, 285-293.

Yang, F. X. (2013). Effects of restaurant satisfaction and knowledge sharing motivation on ewom intentions: the moderating role of technology acceptance factors. Journal of Hospitality \& Tourism Research, 1-35.

Zikmund, W., Babin, B., Carr, J., \& Griffin, M. (2013). Business Research Methods. Cengage Learning. 